\title{
Wastewater as a Resource for Pest Control: An Overview
}

\begin{abstract}
Ana M. Bailón-Salas, ${ }^{\mathrm{a}, \delta}$ Luis A. Ordaz-Diaz, ${ }^{\mathrm{b}}$ Pablito M. López-Serrano, ${ }^{\mathrm{a}}$ Monica Y. Flores-Villegas, ${ }^{b}$ and Pedro A. Dominguez-Calleros ${ }^{a}, *$

Pests have a negative impact on the economy and the environment. There is an increased urgency for adequate pest control because many pests show high adaptation and climate change has created favorable circumstances for pests. For pest control, synthetic chemicals are used that are lethal to non-target organisms and are toxic to pollinators and aquatic invertebrates. Chemical compounds in plants and derivatives from lignocellulosic materials act against pests. The wastewater from lignocellulosic biomass is a potential source of new compounds with bactericidal, fungicidal, and pesticidal effects that have demonstrated inhibitory activity against plant pathogens. Fungicidal, nematicidal, insecticidal, larvicidal, and bactericidal activities have been proven. Inorganic and organic compounds, such as phenols, aldehydes, esters, and furanics, are the main ones identified. Due to the antimicrobial activity of wastewater, applying it to the soil can modify the composition and structure of key microbial communities. Deep research about richness, biodiversity, functionality, and microbials is needed. This review provides a comprehensive overview of wastewater types that have been applied and possible sources to obtain potential compounds for pest control. Moreover, associated active compounds, recovery techniques, and environmental impacts are reviewed.
\end{abstract}

Keywords: Biological control; Metabolites sources; Liquid waste; Lignocellulosic biomass

Contact information: a: Facultad de Ciencias Forestales, Doctorado Institucional en Ciencias Agropecuarias y Forestales, Río Papaloapan, Valle del Sur, C.P. 34120 Durango, Durango, México; b: Ingeniería en Tecnología Ambiental, Universidad Politécnica de Durango, Carr. Dgo-Mex Km 9.5, Col. Dolores Hidalgo, 34300, Durango, Durango, México; ${ }^{\delta}$ postdoctoral student;

* Corresponding author: pdomingc@hotmail.com

\section{CONTENTS}

Introduction. 6402

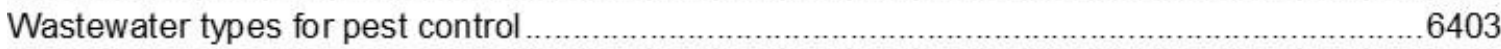

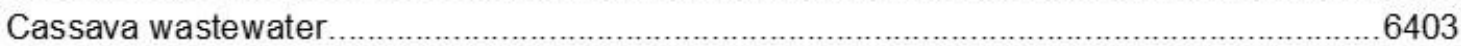

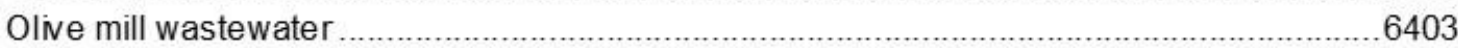

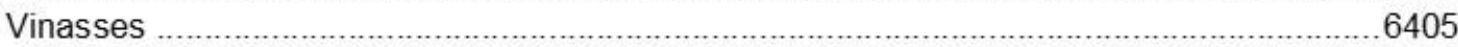

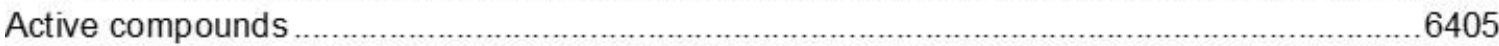

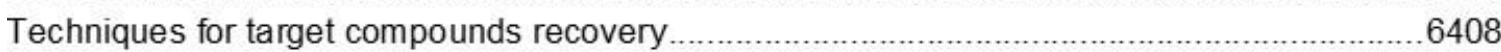

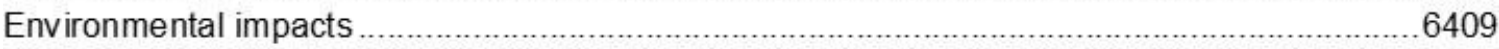

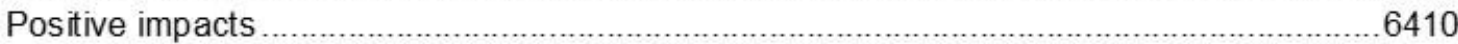

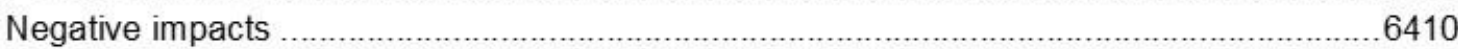

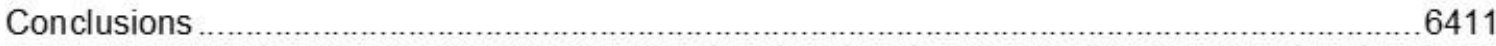




\section{INTRODUCTION}

Pests generate negative impacts because they decrease the quality and yield of crops (Savary et al. 2019). There is increased urgency because pests generate economic losses five times more than fires (Logan et al. 2003). Additionally, pathogens and pests are highly adaptable (Wingfield et al. 2015) and climate change can favor outbreaks and their extension (Rubin-Aguirre et al. 2015; Jactel et al. 2019). More so, the level of economic loss due to injuries caused by insects and pests is multifactorial, because they depend on the type of crop, temporal nature, and spatial location (Capinera 2020).

Plants contain chemical compounds that help fight disease and insects, for instance, phytohormones and secondary metabolites. The development of insecticides started from this discovery, and produced similar but more effective chemicals (Bednarek 2012; Erb et al. 2012; Matthews 2018). In contrast, lignocellulosic biomass is a copious and cheap source for pulp and paper, textile manufacturing, and agriculture in the forms of corn, wheat, rice, sorghum, barley, and sugarcane byproducts (Reddy and Yang 2005). Cellulose, hemicelluloses, and lignin are the main polymeric components (Sarip et al. 2016), the latter being the second most abundant biopolymer after cellulose (Demuner et al. 2019). In the lignocellulosic biomass pretreatment, the cellulose-hemicellulose-lignin structures are altered, facilitating the hydrolysis of cellulose and increasing the fermentable glucose concentration, whereby lignin derivatives are obtained (Kim 2018). Lignin contains several functional groups, such as phenolic hydroxyl, carboxylic, carbonyl, and methoxyl groups. Biological activities of phenolic hydroxyl and methoxyl groups (Espinoza-Acosta et al. 2016) were highlighted as antioxidant or antimicrobial activities (Alzagameem et al. 2019; Jinxiang et al. 2020). In addition, chemical compounds derived from the by-products from lignocellulosic materials provide protection for pests (Villaverde et al. 2016).

For pest control, methyl bromide gas was widely used as a broad-spectrum fumigant until 2005, when it was banned (Wedge et al. 2001). Neonicotinoid pesticides have become the most widely used class of insecticides in the world (Simon-Delso et al. 2014). However, they present significant environmental impacts (Saeed et al. 2019). For example, methyl bromide produces neurotoxicity and is a stratospheric ozone depleter (Wedge et al. 2001), the fipronil is toxic to pollinators and aquatic invertebrates (Sadaria et al. 2019), and most insecticides can be lethal to non-target organisms (Simon-Delso et al. 2014). In addition, pesticides are considered a powerful biological risk because they can persist in the environment for years (Sharma et al. 2020). Chemical fungicides are widely used because they are effective in sterilizing (Lin et al. 2020). However, they have also been reported to induce resistance in fungal plant pathogens (Swett et al. 2020). For the control of phytoparasitic nematodes, fumigants have been used that have the ability to eliminate not only target organisms but also affect the microbial population in the soil (Ntalli et al. 2020). This leads researchers to search for alternatives to control pests.

The use of living biological organisms or their metabolites for pest control is called bio-pesticides (Butu et al. 2020). The demand is increasing to limit the use of chemical pesticides and to replace them with agents that have no or less negative effects on the environment (Di Ilio and Cristofaro 2020; Rashwan and Hammad 2020). Sharma et al. (2020) considered that biopesticides could facilitate increased crop production with or without minimal negative effects. Furthermore, biopesticides are biodegradable, less expensive, and possess less toxicity toward living organisms (Thakur et al. 2020).

There are different alternatives for pest control, such as genetically based resistance (Molinari 2011), integrated pest management (IPM) (Meissle et al. 2010), botanical 
pesticides (Lengai et al. 2020), larvicidal red-algae (Deepak et al. 2019), reductive soil disinfestation (RSD), anaerobic soil disinfestation (Huang et al. 2019), and microbial biopesticides (Thakur et al. 2020), among others. Biopesticide sources exist readily in nature (Thakur et al. 2020), and some have yet to be fully exploited and studied, for example, liquid waste.

Wastewater is a valuable source of biomolecules for different uses; by recovering these compounds, value is added, and at the same time the environmental impact in the treatment of these wastes is reduced (Larif et al. 2015; Ahmad et al. 2020). These wastes may possibly be considered one of the most abundant, cheap, and renewable resources on earth (Gonzalez-Coloma et al. 2013). It is time to change the paradigm and stop seeing them only as waste to treat them as by-products, revalue the "waste" and give them another type of value with sustainable management of these materials (Ordaz-Díaz et al. 2019).

\section{Wastewater Types for Pest Control}

The raw wastewaters used for pest control are cassava, olive mill, vinasses of wine, sugar beet, and sugarcane featuring fungicidal, nematicidal, insecticidal, larvicidal, and bactericidal activities (Table 1).

\section{Cassava Wastewater}

A feature of cassava wastewater is the presence of linamarin and lotaustralin compounds, cyanogenic glycosides that are lost in processing (Padmaja 1995). Near 5 to 7 L of wastewater are generated from a kilogram of fresh cassava root (Watthier et al. 2019). The cassava wastewater has been studied for more than 30 years for possible applications in pest management (Pinto-Zevallos et al. 2018), against insects, nematodes, and fungi (Table 1). The pest species that have been evaluated are Coceus hesperidum L., Meloidogyne spp., and Oidium sp., which are associated mainly with crops of fruit trees and tomato (Lebeda et al. 2015; Abdul-Rassoul 2016; Regmi and Desaeger 2020).

\section{Olive Mill Wastewater}

Olive mill wastewater contains phenolic compounds (Di Mauro et al. 2017). Due to the reducing power of these compounds, bacteria and plants are negatively impacted (Babić et al. 2019). The olive mill wastewater can be used against bacterial, fungal phytopathogens, and weed species (El-Abbassi et al. 2017). Pest mortality is attributed to phenolic compounds (Larif et al. 2013). Hence, polyphenolic fractions of the olive mill wastewater act as a strong natural chemosterilant (Di Ilio and Cristofaro 2020).

Euphyllura olivina and Ceratitis capitata Wiedemann, globally important pests, are Mediterranean parasitoids that affect olive and fruit crops, respectively (Alves et al. 2019; Hougardy et al. 2020). The olive mill wastewater has also shown insecticidal activity against both pests and larvicidal activity against Euphyllura olivina. Furthermore, Aphis citricola, an aphid related to apple orchards infestation (Kou et al. 2020), can be controlled using olive mill wastewater, due to larvicidal activity (Table 1).

Besides being effective against larvae and insects, the olive mill wastewater has also been shown to suppress fungi and bacteria activity (Table 1). 
Table 1. Wastewater Type Used for Pest Control

\begin{tabular}{|c|c|c|c|}
\hline Pest & Activity & Wastewater Type & Reference \\
\hline $\begin{array}{l}\text { Phytophthora parasitica, } \\
\text { Fusarium oxysporum f. sp. } \\
\text { melonis race, F. oxysporum } \\
\text { f. sp. radicis-cucumerinum, } \\
\text { Pythium aphanidermatum, } \\
\text { and Sclerotinia sclerotiorum }\end{array}$ & Fungicidal & $\begin{array}{c}\text { Sugar beet, } \\
\text { sugarcane, and wine } \\
\text { vinasse }\end{array}$ & Santos et al. 2008 \\
\hline Meloidogyne incognita & Nematicidal & Sugar beet vinasse & Núñez-Zofío et al. 2013 \\
\hline Sphenophorus levis & Inconticidal & Suraronno vingcc & Martins et al. 2020 \\
\hline Stomoxys calcitrans & Insecticidal & Sugarcane vinasse & Jelvez Serra et al. 2017 \\
\hline Oregmopyga peruviana & Insecticidal & Wine vinasse & $\begin{array}{l}\text { Dadther-Huaman et al. } \\
2020\end{array}$ \\
\hline Coccus hesperidum L. & Insecticidal & \multirow{3}{*}{ Cassava } & Ponte et al. 1988 \\
\hline Meloidogyne spp. & Nematicidal & & Ponte and Franco 1983 \\
\hline Oidium sp. & Fungicidal & & Santos and Ponte 1993 \\
\hline Euphyllura olivina & \multirow{2}{*}{ Insecticidal } & \multirow{7}{*}{ Olive mill } & Debo et al. 2011 \\
\hline $\begin{array}{c}\text { Ceratitis capitata } \\
\text { Wiedemann }\end{array}$ & & & $\begin{array}{l}\text { Di Ilio and Cristofaro } \\
2020\end{array}$ \\
\hline $\begin{array}{c}\text { Euphyllura olivina and Aphis } \\
\text { citricola }\end{array}$ & Larvicidal & & Larif et al. 2013 \\
\hline Botrytis cinerea & \multirow[b]{3}{*}{ Fungicidal } & & Yangui et al. 2010 \\
\hline $\begin{array}{l}\text { Rhizoctonia solani and } \\
\text { Fusarium oxysporum }\end{array}$ & & & Mohamed et al. 2015 \\
\hline $\begin{array}{c}\text { Fusarium sambucinum, } \\
\text { Verticillium } \\
\text { dahliae, and Alternaria } \\
\text { solani }\end{array}$ & & & Yangui et al. 2009 \\
\hline $\begin{array}{l}\text { Pseudomonas syringae and } \\
\text { Xanthomonas campestris }\end{array}$ & Bactericidal & & Yangui et al. 2010 \\
\hline
\end{tabular}

The fungicidal activity of olive mill wastewater has been tested against Botrytis cinérea, Rhizoctonia solani, Fusarium oxysporum, Fusarium sambucinum, Verticillium dahlia, and Alternaria solani (Table 1). These fungi affect various crops and the economic losses they generate are considerable. For example, Botrytis cinérea, a necrotrophic pathogen, produces severe crop losses worldwide in a wide variety of plant species (Hahn et al. 2014). Rhizoctonia solani is a root pathogen that affects cereal crops (Paulitz and Schroeder 2005). Fusarium oxysporum is a soil and seed-borne disease and is one of the main pathogens of dry rot (Tiwari et al. 2020). Fusarium sambucinum (root rot disease) and Fusarium oxysporum cause potato infection (Yangui et al. 2009; Piłsyk et al. 2015; Tiwari et al. 2020). Verticillium dahliae is a vascular pathogen that causes wilt and death of 400 cultivated and non-cultivated plant species including the tomato plants. Alternaria solani affects different parts of the plant from root rot to even cause tomato and potato rot (Yangui et al. 2009; EFSA Panel on Plant Health PLH 2014).

Pseudomonas syringae is an extracellular bacteria and is considered one of the main bacterial pathogens of plants (Mansfield et al. 2012; Xin et al. 2018). Xanthomonas campestris is a bacteria able to cause black rot infection in cruciferous plants (Papaianni et al. 2020). Due to the bactericidal activity of olive mill wastewater, both phytopathogenic bacteria are inhibited by this liquid waste (Table 1). 


\section{Vinasses}

The vinasse, a liquid residue from alcoholic fermentation, contains various compounds such as alcohols, aldehydes, phenols, and acids (Couallier et al. 2006; Freitas et al. 2018; Fuess et al. 2018). In some cases, these compounds are undesirable. For example, in anaerobic wastewater treatment, phenolic compounds should be removed, because they participate as inhibitors (Borja et al. 1993; Ao et al. 2020). However, some of the compounds have a positive environmental and economic value.

Raw vinasse has proven useful in other fields of research. Phanapavudhikul (1999) observed an eradication of insects by adding the sugarcane vinasse to the soil, associating it with oxygen depletion. The first reports of vinasse use to control phytopathogenic fungi date back to 2008. It was reported that wine vinasse showed $100 \%$ efficacy in suppressing the growth of phytopathogenic fungi (Santos et al. 2008). Afterward, the sugar beet vinasse was tested for the control of nematodes in pepper crops, as an alternative to the disinfection of soil-borne pathogens (Núñez-Zofío et al. 2013). Furthermore, the vinasse compounds can be used as chemical attractants (Martins et al. 2020). Recently, in the treatment of mycoremediation, Fernandes et al. (2020) reported a decrease in the growth rate of fungi using a wine vinasse concentration higher than $60 \%$.

The vinasses have been shown to be effective against fungi, insects, and nematodes. The fungicidal activity have been tested against Phytophthora parasitica, Fusarium oxysporum f. sp. melonis race, F. oxysporum f. sp. radicis-cucumerinum, Pythium aphanidermatum, and Sclerotinia sclerotiorum (Table 1). The Phytophthora genus is one of the most devastating pathogens to a wide range of crop plants (El-Sayed and Ali 2020). Phytophthora parasitica is a soilborne pathogen (Meng et al. 2014). This oomycete mainly affects tobacco (Hou et al. 2012), tomato crops (Vigo et al. 2000), and the citrus industry (Boava et al. 2011). Fusarium oxysporum f. sp. melonis race is one of the most important diseases causing tremendous losses in melon fruit (Almasi 2019). F. oxysporum f. sp. radicis-cucumerinum is a vascular wilt fungus and is associated with cucumber crops (Markakis et al. 2016). Pythium aphanidermatum is the most devastating pathogen that affects turmeric and Sclerotinia sclerotiorum is capable of attacking more than 400 crop species (Boland and Hall 1994; Chand et al. 2016).

Moreover, the insecticidal activity was evaluated using sugarcane and wine vinasse against Sphenophorus levis, Stomoxys calcitrans, and Oregmopyga peruviana (Table 1). Sphenophorus levis affects the sugarcane crops, Stomoxys calcitrans is a stable fly that acts as a mechanical vector for the lumpy skin disease virus on cattle, and Oregmopyga peruviana is a vine pest (Casteliani et al. 2020; Dadther-Huaman et al. 2020; Paslaru et al. 2020).

Meloidogyne incognita, a root-knot nematode damaging vegetable crops (Collange et al. 2011), also has been tested using sugar beet vinasse for pest control (Table 1).

Due to this potential, vinasse can be studied as a source of biocide for the prevention and control of various pests.

\section{Active Compounds}

Esters, acids, aldehydes, ketones, aromatics, alkanes, alcohols, nitrosamides, and terpenoids, are acting in a synergistic inhibitory manner of fungi and bacteria (Saxena and Strobel 2020). Table 2 shows the compounds present in wastewater, a diverse source (vinasses, olive mill, and cassava) that is of great interest for the control pests. Phenols, organic acids, aldehydes, esters, furanic, and inorganic compounds are the main ones. 
Table 2. Compounds Identified in Wastewater Samples of Interest in Pest Control

\begin{tabular}{|c|c|c|c|c|}
\hline $\begin{array}{l}\text { Wastewater } \\
\text { Type }\end{array}$ & Classification & Compounds & Content & $\begin{array}{c}\text { Reference } \\
\text { Díaz et al. } \\
2012\end{array}$ \\
\hline \multirow{3}{*}{$\begin{array}{c}\text { Wine } \\
\text { Vinasses }\end{array}$} & \multirow{11}{*}{ Phenol } & Gallic acid & $10.83 \mathrm{~g} / \mathrm{L}$ & \multirow{3}{*}{$\begin{array}{l}\text { Díaz et al. } \\
2012\end{array}$} \\
\hline & & Hydroxytyrosol & ND & \\
\hline & & Total phenols & $18.9 \mathrm{~g} / \mathrm{L}$ & \\
\hline Baijiu Vinasse & & Ferulic acids & $1.674 \mathrm{mg} / \mathrm{K}$ & $\begin{array}{l}\text { Wang et al. } \\
2019\end{array}$ \\
\hline $\begin{array}{c}\text { Sugar Beet } \\
\text { Vinasse }\end{array}$ & & Ferulic acid & $<5 \mathrm{mg} / \mathrm{L}$ & $\begin{array}{c}\text { Bostyn et al. } \\
2009\end{array}$ \\
\hline \multirow{3}{*}{$\begin{array}{c}\text { Tequila } \\
\text { Vinasse }\end{array}$} & & Eugenol & $0.9 \mathrm{mg} / \mathrm{L}$ & \multirow{3}{*}{$\begin{array}{c}\text { Félix et al. } \\
2018\end{array}$} \\
\hline & & 2,4-di-tert-butylphenol & $90 \mathrm{mg} / \mathrm{L}$ & \\
\hline & & 4-(2-hydroxyethyl) phenol & ND & \\
\hline $\begin{array}{l}\text { Mezcal } \\
\text { Vinasses }\end{array}$ & & Gallic acid & $\begin{array}{c}478 \text { to } 542 \\
\mathrm{mg} / \mathrm{L}\end{array}$ & $\begin{array}{c}\text { Robles- } \\
\text { González et } \\
\text { al. } 2012\end{array}$ \\
\hline \multirow{3}{*}{$\begin{array}{l}\text { Olive Mill } \\
\text { Wastewater }\end{array}$} & & Gallic acid & ND & $\begin{array}{c}\text { Puoci et al. } \\
2012 \\
\end{array}$ \\
\hline & & Oleuropein & 14.32 & \multirow{2}{*}{$\begin{array}{c}\text { Di Mauro et } \\
\text { al. } 2017\end{array}$} \\
\hline & & Hydroxytyrosol & $\begin{array}{c}267.17 \text { to } \\
821.86 \mathrm{mg} / \mathrm{L}\end{array}$ & \\
\hline \multirow{6}{*}{$\begin{array}{l}\text { Tequila } \\
\text { Vinasse }\end{array}$} & Aldehydes & Benzaldehyde & ND & \multirow{6}{*}{$\begin{array}{l}\text { Félix et al. } \\
2018\end{array}$} \\
\hline & Esters & $\begin{array}{l}\text { Ethyl butanoate, ethyl } \\
\text { lactate, and ethyl palmitate }\end{array}$ & ND & \\
\hline & Alkanes & $\begin{array}{l}\text { Dodecane, tetradecane, } \\
\text { and eicosane }\end{array}$ & ND & \\
\hline & \multirow{2}{*}{$\begin{array}{c}\text { Furanic } \\
\text { compounds }\end{array}$} & Furfural & $50 \mathrm{mg} / \mathrm{L}$ & \\
\hline & & 5-methyl furfural & ND & \\
\hline & & $\begin{array}{l}\text { 4H-pyran-4-one,2,3- } \\
\text { dihydro-3,5-dihydroxy-6- } \\
\text { methyl and pyrrolo[1,2-a] } \\
\text { pyrazine-1,4-dione, } \\
\text { hexahydro-3-(2- } \\
\text { methylpropyl) }\end{array}$ & ND & \\
\hline $\begin{array}{l}\text { Sugarcane } \\
\text { Vinasse }\end{array}$ & Organic acids & Lactic acid & $\begin{array}{c}1.2 \times 10^{-1} \\
\mathrm{~mol} / \mathrm{L}\end{array}$ & $\begin{array}{l}\text { Sedenho et } \\
\text { al. } 2017\end{array}$ \\
\hline \multirow[t]{2}{*}{$\begin{array}{c}\text { Cassava } \\
\text { Wastewater }\end{array}$} & \multirow[t]{2}{*}{ Triazine } & Cyanuric acid & ND & $\begin{array}{l}\text { Pinto-Zevallos } \\
\text { et al. } 2018\end{array}$ \\
\hline & & Free cyanide & $257.20 \mathrm{mg} / \mathrm{L}$ & $\begin{array}{c}\text { Neves et al. } \\
2014\end{array}$ \\
\hline $\begin{array}{l}\text { Sugarcane } \\
\text { Vinasse }\end{array}$ & - & Melanoidins & $16600 \mathrm{~g} / \mathrm{L}$ & $\begin{array}{c}\text { Kaushik et al. } \\
2018\end{array}$ \\
\hline
\end{tabular}

$\mathrm{ND}=$ no data

Pest mortality has been attributed to the presence of phenolic compounds (Larif et al. 2013), due to being part of the protection system of plants against pests (Patzke and Schieber 2018). Lignin or lignin-rich biomass are a source of phenols, which can be obtained through the hydrothermal process (Peng et al. 2019). Therefore processes that contain lignin and are subjected to high temperatures will contain phenolic compounds in their wastewater, thanks to thermal hydrolysis. The wastewater contains phenols, such as hydroxytyrosol, gallic acid, ferulic acid, eugenol, oleuropein, 2,4-di-tert-butylphenol, and 4-(2-hydroxyethyl) phenol, which can be used or recovered for pest control (Table 2). For instance, hydroxytyrosol metabolite, a phytochemical polyphenol with antioxidant 
properties, has exhibited antimicrobial activity (Bisignano et al. 1999), insecticidal activity (Debo et al. 2011), disinfectant activity on seeds (Yangui et al. 2009), and fungicide activity (Yangui et al. 2010; Khan and Murphy 2020). The main sources of hydroxytyrosol are olive and wine (Rebollo-Romero et al. 2020). However, it is also reported in wine vinasse and olive mill wastewater (Table 2). Gallic acid, a secondary polyphenolic metabolite, is considered one of the most powerful antioxidants and has been reported in most plants (Erukainure et al. 2018; Martínez et al. 2018). From an environmental point of view, gallic acid present in agro-industrial wastewaters must be removed, due to its toxicity (Víctor-Ortega and Airado-Rodríguez 2018), because it can affect the microbial communities in wastewater discharge points. However, it can be used for the management of bacteria pathogen pests, as Borges et al. (2013) reported bactericidal activity. This phenolic compound is available in olive mill wastewater, wine, and mezcal vinasses, as an alternate source (Table 2). Ferulic acid is a phenolic compound extremely abundant and found widely in nature (Rosazza et al. 1995), showing fungicidal and bactericidal activities (Borges et al. 2013; Patzke and Schieber 2018). Based on Table 2, this compound has been reported in baijiu and sugar-beet vinasses. The eugenol (4-allyl-2-methoxyphenol) found in tequila vinasse (Table 2); it is an acaricidal agent, having fungicidal and bactericidal activities (Abd El-Baky and Hashem 2016; Shang et al. 2020). Oleuropein shows bactericidal and fungicidal activities, mainly contained in olives (Bisignano et al. 1999), and, as shown in Table 2, was also in the wastewater. Additionally, 2, 4-di-tert-butylphenol demonstrated fungicidal and acaricidal activity (Dharni et al. 2014; Chen and Dai 2015; Varsha et al. 2015), and 4-(2-hydroxyethyl) phenol showed nematicidal activity (Yang et al. 2012).

Therefore, phenolic compounds are considered a natural alternative to conventional plant protection agents (Patzke and Schieber 2018). Additionally, the recovery of phenols and the obtaining of added value products is attractive from industrial and environmental points of view (Víctor-Ortega and Airado-Rodríguez 2018).

Tequila vinasse compounds such as aldehydes, esters, alkanes, furanic compounds, and pyrans can be used for pest control. The benzaldehyde identified in tequila vinasse (Table 2) could be applicable for developing novel insecticides for agricultural use due to having been tested as agents effectively inhibiting fungi, insects, and microbials (Kim et al. 2011; Ullah et al. 2015). This compound is present in Agave alcoholic beverages such as bacanora, mezcal from $A$. angustifolia, mezcal from $A$. durangensis, mezcal from $A$. potatorum, mezcal from A. salmiana, raicilla, sisal, sotol, tequila, and pulque (De León Rodríguez et al. 2008). Therefore it is also found in the vinasse of each process. The ethyl butanoate, an ester, was identified in male rectal glands during periods of sexual activity in the banana fruit fly (Bactrocera musae Tryon). Therefore, ethyl butanoate could be used to control this pest as a possible biological role of these compounds in the mating system (Noushini et al. 2020). The ethyl lactate can be generated from biomass raw materials through fermentation (Pereira et al. 2011). As shown in Table 2, it is also present in liquid distillation wastes of tequila. A mix of ethyl lactate and acetic acid exhibits an antifungal effect (Sleven et al. 2016). Ethyl palmitate was identified as a component of the pheromone from the brood of bees, and this volatile compound attracts the small hive beetle, a pest of honeybees. This finding can be useful for trap development and management (Dekebo and Jung 2020). Other compounds present in the tequila vinasse, such as dodecane, tetradecane, and eicosane (Table 1), are the female sex pheromone compounds of Paranthrene diaphana Dalla Torre and Strand (Lep. Sesiidae), a destructive pest of willow trees (Minaeimoghadam et al. 2017). Therefore, the vinasse could be used to attract and control 
this pest. Moreover, furanic compounds with antifungal activity, such as furfural and 5methyl furfural, can help decrease the commercial antifungal agrochemical dose against Alternaria mali (Jung et al. 2007). Additionally, 4H-pyran-4-one, 2,3-dihydro-3,5dihydroxy-6-methyl (Table 2) is part of a mixture that shows insecticidal, larvicidal, and pupicidal effects (Ravindran et al. 2020), and pyrrolo[1,2-a] pyrazine-1,4-dione, hexahydro-3-(2-methylpropyl) (Table 2) has an antifungal function (Kannabiran 2016).

Lactic acid identified in sugarcane vinasse (Table 2) showed antifungal activity against Aspergillus, Penicillium, and Fusarium genera (Lind et al. 2005). L-Lactic acid has used as a pesticide and can be obtained through a fermentation process (Liu et al. 2013). The cyanide that is present in cassava wastewater (Table 2) acts as a natural plant defense against pests (Pinto-Zevallos et al. 2018). This is the case for the cyanogenic glycosides in wastewater that comes from the soaking stage in the manufacture of flour from cassava (Alitubeera et al. 2019).

Melanoidins are the end products of the Maillard reaction between carbohydrates and amino compounds (Cämmerer and Kroh (1995). They are found in vinasses (Table 2), and have antimicrobial activity (Kaushik et al. 2018).

It can be seen in Table 2 that the composition of wastewater is diverse. Koul and Walia (2009) mentioned that this can be an advantage because the possibility of pests developing resistance is reduced.

\section{Techniques for Target Compounds Recovery}

The direct application of raw wastewater has been the most used for the evaluation of the power against pests. However, it is possible to recover the target compounds.

For the compound's recovery in rich phenolic wastewater, magnetic extraction, ultrasound-assisted extraction, solvent extraction, adsorption, or combined processes, such as hydrolysis-purification and extraction-adsorption, are used (Table 3). However, sometimes the suspended matter needs to be removed by flocculation, as a preliminary stage (Azzam and Hazaimeh 2021).

Some of the solvent extraction process steps are acidification or condensing, delipidation extraction, and purification used for phenol recovery in olive mill wastewater (Deng et al. 2017; Çelik et al. 2020). The acidification with acetic acid allows hydroxytyrosol enrichment (Debo et al. 2011), and ultrasound-assisted extraction could increase the yield of phenolic compounds (Deng et al. 2017). In the ultrasound-assisted extraction, less solvent is required (Albero et al. 2015), which makes it a more environmentally friendly technique. To remove lipids, a fraction delipidation step is employed, and hexane is the most used (Rubio-Senent et al. 2017). Ethyl acetate is the solvent more commonly used for the recovery of high added-value compounds from wastewaters (Table 3). This solvent was the most efficient for the recovery of phenolic monomers from olive mill wastewater (Allouche et al. 2004), and the system was able to reach a total recovery of polyphenols (Bostyn et al. 2009). After extraction, the resins are used in the purification step to increase the amount and purity of phenolic compounds (Çelik et al. 2020).

Despite adsorbents or chemicals used in conventional treatment (absorption and extraction) are cheaper than advanced treatments, both show high efficiencies (Villegas et al. 2016). It is even possible to reduce costs further with the use of low-cost adsorption media (Daragon et al. 2014). 
Table 3. Processes Used for the Recovery of Phenol in Wastewater

\begin{tabular}{|c|c|c|c|c|c|}
\hline $\begin{array}{c}\text { Wastewater } \\
\text { Type }\end{array}$ & Compounds & Solvent & pH & Process & Reference \\
\hline \multirow{4}{*}{$\begin{array}{c}\text { Olive Mill } \\
\text { Wastewater }\end{array}$} & \multirow[b]{2}{*}{ Hydroxytyrosol } & Ethyl acetate & 2 & Solvent extraction & $\begin{array}{l}\text { Allouche et } \\
\text { al. } 2004\end{array}$ \\
\hline & & - & 3 & $\begin{array}{l}\text { Hydrolysis (acetic } \\
\text { acid) and } \\
\text { purification (resin) }\end{array}$ & $\begin{array}{c}\text { Debo et al. } \\
2011\end{array}$ \\
\hline & \multirow[b]{2}{*}{ Polyphenols } & \multirow[b]{2}{*}{ Ethyl acetate } & - & $60^{\circ} \mathrm{C}$ & $\begin{array}{l}\text { Larif et al. } \\
2015\end{array}$ \\
\hline & & & & Solvent extraction & $\begin{array}{l}\text { Azzam and } \\
\text { Hazaimeh } \\
2021\end{array}$ \\
\hline $\begin{array}{c}\text { Tequila } \\
\text { Vinasse } \\
\end{array}$ & $\begin{array}{c}\text { Phenolic } \\
\text { compounds }\end{array}$ & & & Adsorption resins & $\begin{array}{l}\text { Sanchez et } \\
\text { al. } 2019\end{array}$ \\
\hline $\begin{array}{l}\text { Sugar Beet } \\
\text { Vinasse }\end{array}$ & Phenolic acids & Ethyl acetate & 4 & Solvent extraction & $\begin{array}{c}\text { Bostyn et al. } \\
2009\end{array}$ \\
\hline $\begin{array}{c}\text { Olive Oil } \\
\text { Wastewater }\end{array}$ & Gallic acid & Ethanol & & $\begin{array}{l}\text { Solvent extraction } \\
\text { and adsorption } \\
\text { (molecularly } \\
\text { imprinted } \\
\text { polymers) }\end{array}$ & $\begin{array}{l}\text { Puoci et al. } \\
2012\end{array}$ \\
\hline \multirow[t]{2}{*}{$\begin{array}{l}\text { Aqueous } \\
\text { Solutions }\end{array}$} & Gallic acid & Ethyl acetate & - & Solvent extraction & $\begin{array}{c}\text { Daneshfar et } \\
\text { al. } 2008\end{array}$ \\
\hline & $\begin{array}{l}\text { Phenolic } \\
\text { compounds }\end{array}$ & - & - & Magnetic extraction & $\begin{array}{c}\text { Deng et al. } \\
2011\end{array}$ \\
\hline $\begin{array}{c}\text { Urban } \\
\text { wastewater }\end{array}$ & $\begin{array}{l}\text { Phenolic } \\
\text { compounds }\end{array}$ & - & - & $\begin{array}{l}\text { Ultrasound- } \\
\text { assisted }\end{array}$ & $\begin{array}{c}\text { Kotowska et } \\
\text { al. } 2014\end{array}$ \\
\hline
\end{tabular}

Table 4 shows that certain wastewater types can have high lignin content, such as wheat straw and kraft pulping effluent. In fact, the dark color in cassava wastewater is due to the presence of lignin breakdown products and lignin phenols (Zhang et al. 2017). Lignin can be used as a raw material in the production of aromatic monomers ( $\mathrm{Gu}$ et al. 2020). Currently, catalytic hydrothermal depolymerization has been used to obtain phenolic monomers from lignin (Roy et al. 2020), with the yield increasing $49 \%$ and $83 \%$ when using mannitol and sucrose addition (Gu et al. 2020).

Table 4. Lignocellulosic Biomass in Wastewater

\begin{tabular}{|c|c|c|c|}
\hline Wastewater Type & Polymer & Content & Reference \\
\hline Olive mill & Lignin & $25.5^{*}$ & Uğurlu and Kula 2007 \\
\hline Wheat straw & Lignin & 310 to $660^{*}$ & Wang 2020 \\
\hline Aspen kraft pulp & Lignin & 230 to $770^{*}$ & Cao et al. 2019 \\
\hline $\begin{array}{c}\text { Sorghum and rice } \\
\text { vinasse }\end{array}$ & Lignin & $14.95^{* *}$ & C \\
\hline
\end{tabular}

${ }^{*} \mathrm{mg} / \mathrm{L},{ }^{* *} \%$ Dry matter

\section{Environmental Impacts}

For pest control, the use of compounds in wastewater should be discussed relative to potential environmental impacts. This source is a new field of research and the possible negative or positive effects have not been studied in depth.

As previously discussed, the positive effect of wastewater use on pests has been shown. However, when the wastewater is in contact with parts of the plants, with the soil, 
or is infiltrated into underground water, the effects are unclear. Possible environmental negative and positive impacts of the use of wastewater for pest control are shown in Table 5 .

\section{Positive Impacts}

The positive impact, in general, is that wastewaters rich in nutrients are considered as an alternative fertilizer, bringing enhanced crop growth, water-holding capacity improvement, and microbial communities in wastewater coadjutant to phenolic degradation in soil (Table 5). Moreover, better soil basal respiration has been reported in cassava wastewater (Table 5), and the increase in $\mathrm{CO}_{2}$ produced in soil respiration is associated with the improvement biological activity of organisms (Phillips and Nickerson 2015). The treated olive mill wastewater germination index increases and water-holding capacity with raw wastewater is improved and does not contain high heavy metal levels (Table 5).

Table 5. Environmental Impacts of Wastewater Used as Pest Control

\begin{tabular}{|c|c|c|c|}
\hline \multirow{2}{*}{$\begin{array}{l}\text { Wastewater } \\
\text { Type }\end{array}$} & \multicolumn{2}{|c|}{ Environmental Impact } & \multirow{2}{*}{ Reference } \\
\hline & Positive & Negative & \\
\hline \multirow{6}{*}{ Cassava } & Increased nutrients & \multirow{4}{*}{$\begin{array}{l}\text { Initial toxic effect on soil } \\
\text { fungal }\end{array}$} & \multirow{4}{*}{$\begin{array}{l}\text { dos Santos Moura } \\
\text { et al. } 2018\end{array}$} \\
\hline & $\begin{array}{c}\text { Total organic carbon } \\
\text { increase }\end{array}$ & & \\
\hline & Microbial biomass increase & & \\
\hline & Better soil basal respiration & & \\
\hline & Soil fertility improvement & Soil hydrophobicity & Abegunrin et al. \\
\hline & Crop yield increase & & Cabral et al. 2010 \\
\hline \multirow{6}{*}{ Olive Mill } & Germination index increase & & \multirow[b]{2}{*}{ Mekki et al. 2013} \\
\hline & $\begin{array}{c}\text { Water-holding capacity } \\
\text { Improvement }\end{array}$ & & \\
\hline & Low heavy metal loads & Seeds germination & Sassi et al. 2006 \\
\hline & $\begin{array}{l}\text { Increased nutrients and } \\
\text { organic matter }\end{array}$ & $\begin{array}{c}\text { Soil infiltration rates } \\
\text { decrease }\end{array}$ & Zema et al. 2019 \\
\hline & & $\begin{array}{c}\text { Soil infiltration rates } \\
\text { decrease }\end{array}$ & $\begin{array}{c}\text { Albalasmeh et al. } \\
2019\end{array}$ \\
\hline & $\begin{array}{l}\text { Microbial communities in } \\
\text { olive mill wastewater } \\
\text { coadjutant to phenolic } \\
\text { degradation in soil }\end{array}$ & & $\begin{array}{c}\text { El Hassani et al. } \\
2020\end{array}$ \\
\hline $\begin{array}{l}\text { Sugar Beet } \\
\text { Vinasse }\end{array}$ & & $\begin{array}{l}\text { Vegetation cover } \\
\text { decreasing }\end{array}$ & Tejada et al. 2009 \\
\hline \multirow{3}{*}{$\begin{array}{l}\text { Sugarcane } \\
\text { Vinasse }\end{array}$} & & Methane emissions & $\begin{array}{l}\text { Do Carmo et al. } \\
2012\end{array}$ \\
\hline & Organic carbon increase & & \multirow{2}{*}{$\begin{array}{l}\text { Soobadar and } \mathrm{Ng} \\
\text { Kee Kwong } 2012\end{array}$} \\
\hline & Crop yield increase & & \\
\hline
\end{tabular}

\section{Negative Impacts}

The raw and concentrated wastewater show negative impacts, for instance, concentrated olive mill wastewater blocked seed germination, and an initial toxic effect on soil fungal activity were identified (Table 5). Sassi et al. (2006) reported a dilution of 1/16 to guarantee full germination. High salt content in vinasse can cause vegetation cover decrease and changes in the structure and porosity of the soil (Tejada et al. 2009). When 
wastewaters are added to the soil, the organic matter accumulation in the soil affects penetration resistance and water repellency (Albalasmeh et al. 2019). A pre-treatment is recommended before applying it to the soil (Abegunrin et al. 2016). To avoid soil hydrophobicity and methane emissions (Table 5), a flocculation process can help.

Wastewater reviewed in this paper contained compounds with antimicrobial activity (Table 2). Therefore, care must be taken when applying it to the soil, as it can modify the composition and structure of key microbial communities. Hence, more research addressed toward microbial communities' impacts on the soil is needed, with a focus on richness, biodiversity, functionality, and microbial adaptability.

To avoid most of the negative environmental impacts associated with raw and concentrated wastewater for pest control, compound recovery processes with fungicidal, acaricidal, nematicidal, bactericidal, and insecticidal activities can be exploited. However, it is necessary to assess the economic and environmental benefits of both options, with more in-depth research.

Otherwise, there is another wastewater type with compounds that can inhibit pests; for example, pulp and paper mill effluent, which is a chlorophenol source (Cheng et al. 2015). Chlorophenols used as herbicides or fungicides on crops were banned, due to human carcinogenic risk (Owuor 2003; Badanthadka and Mehendale 2014). Therefore, pulp and paper mill effluent is not susceptible to use as a source for control pests.

Humans and animals as part of the environment can also be affected by the use of compounds that help control pests and plant diseases. Lin et al. (2020) mention that the use of chemical fungicides in fruits or vegetables could modify the composition of the intestinal microbiota. Therefore, a more complete study is required on the application of wastewater in pest control, either as a direct application or compounds recovery of interest, considering the present economic-environmental impact.

\section{CONCLUSIONS}

1. Wastewater is a potential and alternative source of compounds with bactericidal, fungicidal, and pesticidal effects that have demonstrated inhibitory activity.

2. The phenolic compounds are mainly responsible for pest mortality using wastewater.

3. Because wastewater is a variable chemical composition, its use can be dangerous for the environment. Therefore, the isolation of target compound is recommended.

\section{ACKNOWLEDGMENTS}

The support of the Consejo Nacional de Ciencia y Tecnologia (CONACyT) is gratefully appreciated for the support of the Sistema Nacional de Investigadores (SNI) and the postdoctoral scholarship (130780/20) received by one of the writers. 


\section{REFERENCES CITED}

Abd El-Baky, R. M., and Hashem, Z. S. (2016). "Eugenol and linalool: Comparison of their antibacterial and antifungal activities," African Journal of Microbiology Research 10(44), 1860-1872. DOI: 10.5897/AJMR2016.8283

Abdul-Rassoul, M. S. (2016). "New host plants record for the brown soft scale Coccus hesperidum Linnaeus, 1758 (Hemiptera: Coccidae) in Baghdad province, Iraq," Bulletin of the Iraq Natural History Museum 14(2), 135-139.

Abegunrin, T. P., Awe, G. O., Idowu, D. O., and Adejumobi, M. A. (2016). "Impact of wastewater irrigation on soil physico-chemical properties, growth and water use pattern of two indigenous vegetables in southwest Nigeria," CATENA 139, 167-178. DOI: 10.1016/j.catena.2015.12.014

Ahmad, T., Belwal, T., Li, L., Ramola, S., Aadil, R. M., Xu, Y., and Zisheng, L. (2020). "Utilization of wastewater from edible oil industry, turning waste into valuable products: A review," Trends in Food Science \& Technology 99, 21-33. DOI: 10.1016/j.tifs.2020.02.017

Albalasmeh, A. A., Alajlouni, M. A., Ghariabeh, M. A., and Rusan, M. J. (2019). "Shortterm effects of olive mill wastewater land spreading on soil physical and hydraulic properties," Water, Air, \& Soil Pollution 230(8), article no. 208. DOI: 10.1007/s11270-019-4243-5

Albero, B., Sánchez-Brunete, C., García-Valcárcel, A. I., Pérez, R. A., and Tadeo, J. L. (2015). "Ultrasound-assisted extraction of emerging contaminants from environmental samples," TrAC Trends in Analytical Chemistry 71, 110-118. DOI: 10.1016/j.trac.2015.03.015

Alitubeera, P. H., Eyu, P., Kwesiga, B., Ario, A. R., and Zhu, B. P. (2019). "Outbreak of cyanide poisoning caused by consumption of cassava flour-Kasese District, Uganda, September 2017," Morbidity and Mortality Weekly Report 68(13), 308. DOI: 10.15585/mmwr.mm6813a3

Allouche, N., Fki, I., and Sayadi, S. (2004). "Toward a high yield recovery of antioxidants and purified hydroxytyrosol from olive mill wastewaters," Journal of Agricultural and Food Chemistry 52(2), 267-273. DOI: 10.1021/jf034944u

Almasi, M. A. (2019). "Development of a colorimetric loop-mediated isothermal amplification assay for the visual detection of Fusarium oxysporum f. sp. melonis," Horticultural Plant Journal 5(3), 129-136. DOI: /10.1016/j.hpj.2019.01.004

Alves, T. J. S., Murcia, A., Wanumen, A. C., Wanderley-Teixeira, V., Teixeira, Á. A. C., Ortiz, A., and Medina, P. (2019). "Composition and toxicity of a mixture of essential oils against Mediterranean fruit fly, Ceratitis capitata (Wiedemann) (Diptera: Tephritidae)," Journal of Economic Entomology 112(1), 164-172. DOI: 10.1093/jee/toy 275

Alzagameem, A., Klein, S. E., Bergs, M., Do, X. T., Korte, I., Dohlen, S., Hüwe, C., Kreyenschmidt, J., Kamm, B., Larkins, M., et al. (2019). "Antimicrobial activity of lignin and lignin-derived cellulose and chitosan composites against selected pathogenic and spoilage microorganisms," Polymers 11(4), article no. 670. DOI: 10.3390/polym 11040670

Ao, T., Luo, Y., Chen, Y., Cao, Q., Liu, X., and Li, D. (2020). “Towards zero waste: A valorization route of washing separation and liquid hot water consecutive pretreatment to achieve solid vinasse based biorefinery," Journal of Cleaner Production 248, article ID 119253. DOI: 10.1016/j.jclepro.2019.119253 
Azzam, M. O. J., and Hazaimeh, S. A. (2021). "Olive mill wastewater treatment and valorization by extraction/concentration of hydroxytyrosol and other natural phenols," Process Safety and Environmental Protection 148, 495-523. DOI: 10.1016/j.psep.2020.10.030

Babić, S., Malev, O., Pflieger, M., Lebedev, A. T., Mazur, D. M., Kužić, A., ČožRakovac, R., and Trebše, P. (2019). "Toxicity evaluation of olive oil mill wastewater and its polar fraction using multiple whole-organism bioassays," Science of The Total Environment 686, 903-914. DOI: 10.1016/j.scitotenv.2019.06.046

Badanthadka, M., and Mehendale, H. M. (2014). "Chlorophenols," in: Encyclopedia of Toxicology, P. Wexler (ed.), Elsevier Academic Press, Amsterdam, Netherlands, pp. 896-899. DOI: 10.1016/B978-0-12-386454-3.00281-5

Bednarek, P. (2012). "Chemical warfare or modulators of defense responses - The function of secondary metabolites in plant immunity," Current Opinion in Plant Biology 15(4), 407-414. DOI: 10.1016/j.pbi.2012.03.002

Bisignano, G., Tomaino, A., Cascio, R. L., Crisafi, G., Uccella, N., and Saija, A. (1999). "On the in-vitro antimicrobial activity of oleuropein and hydroxytyrosol," Journal of Pharmacy and Pharmacology 51(8), 971-974. DOI: 10.1211/0022357991773258

Boava, L. P., Cristofani-Yaly, M., Mafra, V. S., Kubo, K., Kishi, L. T., Takita, M. A., Ribeiro-Alves, M., and Machado, M. A. (2011). "Global gene expression of Poncirus trifoliata, Citrus sunki and their hybrids under infection of Phytophthora parasitica," BMC Genomics 12(1), Article number 39. DOI: 10.1186/1471-2164-12-39

Boland, G. J., and Hall, R. (1994). "Index of plant hosts of Sclerotinia sclerotiorum," Canadian Journal of Plant Pathology 16(2), 93-108. DOI: 10.1080/07060669409500766

Borges, A., Ferreira, C., Saavedra, M. J., and Simoes, M. (2013). "Antibacterial activity and mode of action of ferulic and gallic acids against pathogenic bacteria," Microbial Drug Resistance 19(4), 256-265. DOI: 10.1089/mdr.2012.0244

Borja, R., Martin, A., Maestro, R., Luque, M., and Durán, M. M. (1993). "Enhancement of the anaerobic digestion of wine distillery wastewater by the removal of phenolic inhibitors," Bioresource Technology 45(2), 99-104. DOI: 10.1016/09608524(93)90097-U

Bostyn, S., Cagnon, B., and Fauduet, H. (2009). "Optimization by the simplex method of the separation of phenolic acids by high-performance liquid chromatography in wastewater olive and sugar beet vinasse," Talanta 80(1), 1-7. DOI:

10.1016/j.talanta.2009.06.040

Butu, M., Stef, R., Grozea, I., Corneanu, M., and Butnariu, M. (2020). "Biopesticides: Clean and viable technology for healthy environment," in: Bioremediation and Biotechnology, K. Hakeem, R. Bhat, and H. Qadri (eds.), Springer, Cham, Switzerland, pp. 107-151. DOI: 10.1007/978-3-030-35691-0_6

Cabral, J. R., Freitas, P. S. L., Bertonha, A., and Muniz, A. S. (2010). "Effects of wastewater from a cassava industry on soil chemistry and crop yield of lopsided oats (Avena strigosa Schreb.)," Brazilian Archives of Biology and Technology 53(1), 1926. DOI: 10.1590/S1516-89132010000100003

Cämmerer, B., and Kroh, L. W. (1995). "Investigation of the influence of reaction conditions on the elementary composition of melanoidins," Food Chemistry 53(1), 55-59. DOI: 10.1016/0308-8146(95)95786-6

Cao, Y., Wang, J., Wang, Q., Liu, J., Liu, T., Knapp, C. W., and Wang, Y. (2019). "Effect of $\beta$-glycosidase supplementation on vinasse saccharification and L-lactic 
acid fermentation," BioResources 14(1), 1379-1389. DOI:

10.15376/biores.14.1.1379-1389

Capinera, J. (2020). "Introduction," in: Handbook of Vegetable Pests, N. Maragioglio (ed.), Academic Press, London, United Kingdom, pp. 1-21.

Castelian, A., de Fatima Martins, L., Cardoso, J. F. M., Silva, M. S. O., da Silva, R. S. A., Chacon-Orozco, J. G., Casteliani, A. G. B., Půža, V., Harakava, R., and Leite, L. G. (2020). "Behavioral aspects of Sphenophorus levis (Coleoptera: Curculionidae), damage to sugarcane and its natural infection by Steinernema carpocapsae (Nematoda: Rhabditidae)," Crop Protection 137, Article ID 105262. DOI: 10.1016/j.cropro.2020.105262

Çelik, G., Saygın, Ö., and Balcıŏglu, I. A. (2020). "Multistage recovery process of phenolic antioxidants with a focus on hydroxytyrosol from olive mill wastewater concentrates," Separation and Purification Technology 259, Article ID 117757. DOI: 10.1016/j.seppur.2020.117757

Chand, S. K., Nanda, S., Rout, E., Mohanty, J., Mishra, R., and Joshi, R. K. (2016). "Identification and characterization of microRNAs in turmeric (Curcuma longa L.) responsive to infection with the pathogenic fungus Pythium aphanidermatum," Physiological and Molecular Plant Pathology 93, 119-128. DOI:

10.1016/j.pmpp.2016.01.010

Chen, Y., and Dai, G. (2015). "Acaricidal, repellent, and oviposition-deterrent activities of 2,4-di-tert-butylphenol and ethyl oleate against the carmine spider mite Tetranychus cinnabarinus," Journal of Pest Science 88(3), 645-655. DOI: 10.1007/s10340-015-0646-2

Cheng, Z., Yang, R., Wang, B., and Yang, F. (2015). "Chlorophenol degradation in papermaking wastewater through a heterogeneous ozonation process catalyzed by $\mathrm{Fe}$ Mn/sepiolite," BioResources 10(3), 5503-5514. DOI: 10.15376/biores.10.3.55035514

Collange, B., Navarrete, M., Peyre, G., Mateille, T., and Tchamitchian, M. (2011). "Root-knot nematode (Meloidogyne) management in vegetable crop production: The challenge of an agronomic system analysis," Crop Protection 30(10), 1251-1262. DOI: 10.1016/j.cropro.2011.04.016

Couallier, E. M., Ruiz, B. S., Lameloise, M. L., and Decloux, M. (2006). "Usefulness of reverse osmosis in the treatment of condensates arising from the concentration of distillery vinasses," Desalination 196(1-3), 306-317. DOI:

10.1016/j.desal.2006.02.002

Dadther-Huaman, H., Machaca-Paccara, A., and Quispe-Castro, R. (2020). "Effectiveness of nine control methods of Oregmopyga peruviana (Granara de Willink and Diaz) (Hemiptera: Coccoidea: Eriococcidae) in Vitis vinifera L. 'Negra Criolla' and 'Quebranta',' Scientia Agropecuaria 11(1), 95-103. DOI:

10.17268/sci.agropecu.2020.01.11

Daneshfar, A., Ghaziaskar, H. S., and Homayoun, N. (2008). "Solubility of gallic acid in methanol, ethanol, water, and ethyl acetate," Journal of Chemical and Engineering Data 53(3), 776-778. DOI: 10.1021/je700633w

Daragon, G., Trouve, G., Schönnenbeck, C., and Leyssens, G. (2014). "Recovery of an agro-industrial vinasse by adsorption on different wood materials: Parametric study at laboratory scale," BioResources 9(4), 7764-7781. DOI: 10.15376/biores.9.4.79848001 
De León Rodríguez, A., Escalante Minakata, M. D. P., Jiménez García, M. I., Ordoñez Acevedo, L. G., Flores Flores, J. L., and Barba de la Rosa, A. P. (2008).

"Characterization of volatile compounds from ethnic agave alcoholic beverages by gas chromatography-mass spectrometry," Food Technol. Biotechnol. 46 (4) 448-455.

Debo, A., Yangui, T., Dhouib, A., Ksantini, M., and Sayadi, S. (2011). "Efficacy of a hydroxytyrosol-rich preparation from olive mill wastewater for control of olive psyllid, Euphyllura olivina, infestations," Crop Protection 30(12), 1529-1534. DOI: 10.1016/j.cropro.2011.08.006

Deepak, P., Balamuralikrishnan, B., Park, S., Sowmiya, R., Balasubramani, G., Aiswarya, D., Amutha, V., and Perumal, P. (2019). "Phytochemical profiling of marine red alga, Halymenia palmata and its bio-control effects against Dengue Vector, Aedes aegypti," South African Journal of Botany 121, 257-266. DOI: 10.1016/j.sajb.2018.11.011

Dekebo, A., and Jung, C. (2020). "Olfactory responses of Aethina tumida Murray (Coleoptera: Nitidulidae) to some major volatile compounds from hive materials and workers of Apis mellifera," Journal of Asia-Pacific Entomology 23(2), 504-508. DOI: 10.1016/j.aspen.2020.03.002

Demuner, I. F., Colodette, J. L., Demuner, A. J., and Jardim, C. M. (2019). "Biorefinery review: Wide-reaching products through kraft lignin," BioResources 14(3), 75437581. DOI: 10.15376/biores.14.3.Demuner

Deng, J., Xu, Z., Xiang, C., Liu, J., Zhou, L., Li, T., Yang, Z., and Ding, C. (2017). "Comparative evaluation of maceration and ultrasonic-assisted extraction of phenolic compounds from fresh olives," Ultrasonics Sonochemistry 37, 328-334. DOI: 10.1016/j.ultsonch.2017.01.023

Deng, N., Li, M., Zhao, L., Lu, C., de Rooy, S. L., and Warner, I. M. (2011). "Highly efficient extraction of phenolic compounds by use of magnetic room temperature ionic liquids for environmental remediation," Journal of Hazardous Materials 192(3), 1350-1357. DOI: 10.1016/j.jhazmat.2011.06.053

Dharni, S., Sengupta, S., Maurya, A., Samad, A., Srivastava, S. K., Sharma, A., and Patra, D. D. (2014). "Purification, characterization, and in vitro activity of 2,4-di-tertbutylphenol from Pseudomonas monteilii PsF84: Conformational and molecular docking studies," Journal of Agricultural and Food Chemistry 62(26), 6138-6146. DOI: $10.1021 / \mathrm{jf5001138}$

Di Ilio, V., and Cristofaro, M. (2020). "Polyphenolic extracts from the olive mill wastewater as a source of biopesticides and their effects on the life cycle of the Mediterranean fruit fly Ceratitis capitata (Diptera, Tephriditae)," International Journal of Tropical Insect Science Online, 1-8. DOI: 10.1007/s42690-020-00224-6

Di Mauro, M. D., Giardina, R. C., Fava, G., Mirabella, E. F., Acquaviva, R., Renis, M., and D'antona, N. (2017). "Polyphenolic profile and antioxidant activity of olive mill wastewater from two Sicilian olive cultivars: Cerasuola and Nocellara etnea," European Food Research and Technology 243(11), 1895-1903. DOI: 10.1007/s00217-017-2893-3

Díaz, B., Gomes, A., Freitas, M., Fernandes, E., Nogueira, D. R., González, J., Moure, A., Levoso, A., Vinardell, M. P., Mitjans, M., Domínguez, H., and Parajó, J. C. (2012). "Valuable polyphenolic antioxidants from wine vinasses," Food and Bioprocess Technology 5(7), 2708-2716. DOI: 10.1007/s11947-011-0569-8 do Carmo, J. B., Filoso, S., Zotelli, L. C., de Sousa Neto, E. R., Pitombo, L. M., DuarteNeto, P. J., Vargas, V. P., Andrade, C. A., Gava, G. J. C., Rossetto, R., et al. (2012). 
"Infield greenhouse gas emissions from sugarcane soils in Brazil: Effects from synthetic and organic fertilizer application and crop trash accumulation," $G C B$ Bioenergy 5(3), 267-280. DOI: 10.1111/j.1757-1707.2012.01199.x

dos Santos Moura, A., de Medeiros, E. V., da Silva Oliveira, J. E., da Franca, R. F., Lira, A. D., Martins Filho, A. P., and Badji, C. A. (2018). "Does cassava wastewater with a short incubation time affect soil organic carbon, microbial community and enzymatic activities?," CATENA 163, 354-360. DOI: 10.1016/j.catena.2018.01.001

EFSA Panel on Plant Health PLH (2014). "Scientific opinion on the pest categorisation of Verticillium dahliae Kleb," EFSA Journal 12(12), article no. 3928. DOI: 10.2903/j.efsa.2014.3928

El Hassani, F. Z., Fadile, A., Faouzi, M., Zinedine, A., Merzouki, M., and Benlemlih, M. (2020). "The long term effect of olive mill wastewater (OMW) on organic matter humification in a semi-arid soil," Heliyon 6(1), article ID e03181. DOI: 10.1016/j.heliyon.2020.e03181

El-Abbassi, A., Saadaoui, N., Kiai, H., Raiti, J., and Hafidi, A. (2017). "Potential applications of olive mill wastewater as biopesticide for crops protection," Science of The Total Environment 576, 10-21. DOI: 10.1016/j.scitotenv.2016.10.032

El-Sayed, A. S. A., and Ali, G. S. (2020). "Aspergillus flavipes is a novel efficient biocontrol agent of Phytophthora parasitica," Biological Control 140, article ID 104072. DOI: 10.1016/j.biocontrol.2019.104072

Erb, M., Meldau, S., and Howe, G. A. (2012). "Role of phytohormones in insect-specific plant reactions," Trends in Plant Science 17(5), 250-259. DOI:

10.1016/j.tplants.2012.01.003

Erukainure, O. L., Sanni, O., and Islam, M. S. (2018). "Clerodendrum volubile: Phenolics and applications to health," in: Polyphenols: Mechanisms of Action in Human Health and Disease, R. R. Watson, V. R. Preedy, and S. Zibadi (eds.), Academic Press, Cambridge, MA, USA, pp. 53-68. DOI: 10.1016/B978-0-12-813006-3.00006-4

Espinoza-Acosta, J. L., Torres-Chávez, P. I., Ramírez-Wong, B., López-Saiz, C. M., and Montaño-Leyva, B. (2016). "Antioxidant, antimicrobial, and antimutagenic properties of technical lignins and their applications," BioResources 11(2), 5452-5481. DOI: 10.15376/biores.11.2.Espinoza_Acosta

Félix, E., Contreras-Ramos, S. M., Davila-Vazquez, G., Rodríguez-Campos, J., and Marino, E. (2018). "Identification and quantification of volatile compounds found in vinasses from two different processes of tequila production," Energies 11(3), Article Number 490. DOI: 10.3390/en11030490

Fernandes, J. M. C., Sousa, R. M. O. F., Fraga, I., Sampaio, A., Amaral, C., Bezerra, R. M. F., and Dias, A. A. (2020). "Fungal biodegradation and multi-level toxicity assessment of vinasse from distillation of winemaking by-products," Chemosphere 238, Article ID 124572. DOI: 10.1016/j.chemosphere.2019.124572

Freitas, P. V., da Silva, D. R., Beluomini, M. A., da Silva, J. L., and Stradiotto, N. R. (2018). "Determination of phenolic acids in sugarcane vinasse by HPLC with pulse amperometry," Journal of Analytical Methods in Chemistry 2018, Article ID 4869487. DOI: 10.1155/2018/4869487

Fuess, L., Garcia, M. L., and Zaiat, M. (2018). "Seasonal characterization of sugarcane vinasse: Assessing environmental impacts from fertirrigation and the bioenergy recovery potential through biodigestion," Science of The Total Environment 634, Article ID 4686011. DOI: 10.1016/j.scitotenv.2018.03.326 
Gonzalez-Coloma, A., Reina, M., Díaz, C., Fraga, B. M., and Santana-Meridas, O. (2013). "Natural product-based biopesticides for insect control" in: Chemistry, Molecular Sciences and Chemical Engineering, Elsevier, Amsterdam, Netherlands, pp. 237-268. DOI: 10.1016/B978-0-12-409547-2.02770-0

Gu, S., Choi, J. W., Lee, H., Suh, D. J., Choi, J., and Ha, J. M. (2020).” Improved catalytic depolymerization of lignin waste using carbohydrate derivatives," Environmental Pollution 268(Part A), article ID 115674. DOI: 10.1016/j.envpol.2020.115674

Hahn, M., Viaud, M., and van Kan, J. (2014). "The genome of Botrytiscinerea, a ubiquitous broad host range necrotroph," in: Genomics of Plant-associated Fungi and Oomycetes: Dicot Pathogens, Springer, Berlin, Germany pp. 19-44. DOI: 10.1007/978-3-662-44056-8_2

Hou, Y. T., Ren, J., and Liu, H. J. (2012). "Efficiency of electrolyzed water (EW) on inhibition of Phytophthora parasitica var. nicotianae growth in vitro," Crop Protection 42, 128-133. DOI: 10.1016/j.cropro.2012.06.014

Hougardy, E., Wang, X., Hogg, B. N., Johnson, M. W., Daane, K. M., and Pickett, C. H. (2020). "Current distribution of the olive psyllid, Euphyllura olivina, in California and initial evaluation of the Mediterranean parasitoid Psyllaephagus euphyllurae as a biological control candidate," Insects 11(3), article no. 146. DOI: 10.3390/insects 11030146

Huang, X., Zhao, J., Zhou, X., Zhang, J., and Cai, Z. (2019). "Differential responses of soil bacterial community and functional diversity to reductive soil disinfestation and chemical soil disinfestation," Geoderma 348, 124-134. DOI:

10.1016/j.geoderma.2019.04.027

Jactel, H., Koricheva, J., and Castagneyrol, B. (2019). "Responses of forest insect pests to climate change: Not so simple," Current Opinion in Insect Science 35, 103-108. DOI: 10.1016/j.cois.2019.07.010

Jelvez Serra, N. S., Goulart, H. F., Triana, M. F., Dos Santos Tavares, S., Almeida, C. I. M., Da Costa, J. G., Santana, A. E. G., and Zhu, J. J. (2017). "Identification of stable fly attractant compounds in vinasse, a byproduct of sugarcane-ethanol distillation," Medical and Veterinary Entomology 31(4), 381-391. DOI: 10.1111/mve.12246

Jinxiang, C., Yang, J., Lanlan, M., Li, J., Nasir, S., and Kyung, K. C. (2020). "Structureantioxidant activity relationship of methoxy, phenolic hydroxyl, and carboxylic acid groups of phenolic acids," Scientific Reports (Nature Publisher Group) 10(1), article no. 2611. DOI: 10.1038/s41598-020-59451-z

Jung, K. H., You, S. K., Moon, S. K., and Lee, U. S. (2007). "Furfural from pine needle extract inhibits the growth of a plant pathogenic fungus, Alternaria mali," Mycobiology 35(1), 39-43. DOI: 10.4489/myco.2007.35.1.039

Kannabiran, K. (2016). "Bioactivity of pyrrolo [1, 2-a] pyrazine-1, 4-dione, hexahydro-3(phenylmethyl)-extracted from Streptomyces sp. VITPK9 isolated from the salt spring habitat of Manipur, India," Asian Journal of Pharmaceutics 10(4), 265-270. DOI: 10.22377/ajp.v10i04.865

Kaushik, A., Basu, S., Batra, V. S., and Balakrishnan, M. (2018). "Fractionation of sugarcane molasses distillery wastewater and evaluation of antioxidant and antimicrobial characteristics," Industrial Crops and Products 118, 73-80. DOI: 10.1016/j.indcrop.2018.03.040 
Khan, M. F., and Murphy, C. D. (2020). "3-Hydroxytyrosol regulates biofilm growth in Cunninghamella elegans," Fungal Biology In Press, Corrected proof available online. DOI: $10.1016 /$ j.funbio.2020.10.011

Kim, D. (2018). "Physico-chemical conversion of lignocellulose: Inhibitor effects and detoxification strategies: A mini review," Molecules 23(2), Article number 309. DOI: 10.3390/molecules23020309

Kim, J. H., Chan, K. L., Mahoney, N., and Campbell, B. C. (2011). "Antifungal activity of redox-active benzaldehydes that target cellular antioxidation," Annals of Clinical Microbiology and Antimicrobials 10(1), article no.23. DOI:10.1186/1476-0711-10-23

Kotowska, U., Kapelewska, J., and Sturgulewska, J. (2014). "Determination of phenols and pharmaceuticals in municipal wastewaters from Polish treatment plants by ultrasound-assisted emulsification-microextraction followed by GC-MS," Environmental Science and Pollution Research 21(1), 660-673. DOI: 10.1007/s11356-013-1904-6

Kou, H., Sun, Y., Dong, Z., and Zhang, Z. (2020). "Comparison between sustained effects of spray and injection thiamethoxam on apple aphids and non-target insects in apple orchard," Ecotoxicology and Environmental Safety 207, article ID 111307. DOI: $10.1016 /$ j.ecoenv.2020.111307

Koul, O., and Walia, S. (2009). "Comparing impacts of plant extracts and pure allelochemicals and implications for pest control," CAB Reviews: Perspectives in Agriculture, Veterinary Science, Nutrition and Natural Resources 4(49), 1-30. DOI: 10.1079/PAVSNNR20094049

Larif, M., Ouhssine, M., Soulaymani, A., and Elmidaoui, A. (2015). "Potential effluent oil mills and antibacterial activity polyphenols against some pathogenic strains," Research on Chemical Intermediates 41(2), 1213-1225. DOI: 10.1007/s11164-0131267-0

Larif, M., Zarrouk, A., Soulaymani, A., and Elmidaoui, A. (2013). "New innovation in order to recover the polyphenols of olive mill wastewater extracts for use as a biopesticide against the Euphyllura olivina and Aphis citricola," Research on Chemical Intermediates 39(9), 4303-4313. DOI: 10.1007/s11164-012-0947-5

Lebeda, A., Mieslerová, B., Jankovics, T., Kiss, L., and Van der Linde, E. J. (2015). "First detection of tomato powdery mildew caused by Oidium neolycopersici in South Africa," South African Journal of Botany 99, 153-157. DOI: 10.1016/j.sajb.2015.03.196

Lengai, G. M. W., Muthomi, J. W., and Mbega, E. R. (2020). "Phytochemical activity and role of botanical pesticides in pest management for sustainable agricultural crop production," Scientific African 7, Article ID e00239. DOI:

10.1016/j.sciaf.2019.e00239

Lin, S., Tang, T., Cang, T., Yu, S., Ying, Z., Gu, S., and Zhang, Q. (2020). “The distributions of three fungicides in vegetables and their potential health risks in Zhejiang, China: A 3-year study (2015-2017)," Environmental Pollution 267, 115481. DOI: 10.1016/j.envpol.2020.115481

Lind, H., Jonsson, H., and Schnürer, J. (2005). "Antifungal effect of dairy propionibacteria - contribution of organic acids," International Journal of Food Microbiology 98(2), 157-165. DOI: 10.1016/j.ijfoodmicro.2004.05.020

Liu, J., Wang, Q., Wang, S., Sun, X., Ma, H., and Tushiro, Y. (2013). "Effects of pretreatment on the microbial community and l-lactic acid production in vinasse 
fermentation," Journal of biotechnology 164(2), 260-265. DOI:

10.1016/j.jbiotec.2012.08.014

Logan, J. A., Régnière, J., and Powell, J. A. (2003). "Assessing the impacts of global warming on forest pest dynamics," Frontiers in Ecology and the Environment 1(3), 130-137. DOI: 10.1890/1540-9295(2003)001[0130:ATIOGW]2.0.CO;2

Mansfield, J., Genin, S., Magori, S., Citovsky, V., Sriariyanum, M., Ronald, P., Dow, M., Verdier, V., Beer, S. V., Machado, M. A., et al. (2012). "Top 10 plant pathogenic bacteria in molecular plant pathology," Molecular Plant Pathology 13(6), 614-629. DOI: 10.1111/j.1364-3703.2012.00804.x

Markakis, E. A., Fountoulakis, M. S., Daskalakis, G. C., Kokkinis, M., and Ligoxigakis, E. K. (2016). "The suppressive effect of compost amendments on Fusarium oxysporum $\mathrm{f}$. sp. radicis-cucumerinum in cucumber and Verticillium dahliae in eggplant," Crop Protection 79, 70-79. DOI: 10.1016/j.cropro.2015.10.015

Martínez, L., Ros, G., and Nieto, G. (2018). "Hydroxytyrosol: Health benefits and use as functional ingredient in meat," Medicines 5(1), article no. 13. DOI: 10.3390/medicines5010013

Martins, L. F., Tonelli, M., Bento, J. M. S., Bueno, C. J., and Leite, L. G. (2020). "Attraction of the sugarcane billbug, Sphenophorus levis, to vinasse and its volatile composition," Chemoecology 30, 205-214. DOI: 10.1007/s00049-020-00310-8

Matthews, G. A. (2018). "Pesticides in the early part of the $20^{\text {th }}$ century," in: A History of Pesticides, CABI, London, United Kingdom, pp. 1-27.

Meissle, M., Mouron, P., Musa, T., Bigler, F., Pons, X., Vasileiadis, V. P., Otto, S., Antichi, D., Kiss, J., Pálinkás, J., et al. (2010). "Pests, pesticide use and alternative options in European maize production: Current status and future prospects," Journal of Applied Entomology 134(5), 357-375. DOI: 10.1111/j.1439-0418.2009.01491.x

Mekki, A., Dhouib, A., and Sayadi, S. (2013). "Review: Effects of olive mill wastewater application on soil properties and plants growth," International Journal of Recycling of Organic Waste in Agriculture 2(1), 1-7. DOI: 10.1186/2251-7715-2-15

Meng, Y., Zhang, Q., Ding, W., and Shan, W. (2014). "Phytophthora parasitica: A model oomycete plant pathogen," Mycology 5(2), 43-51. DOI: 10.1080/21501203.2014.917734

Minaeimoghadam, M., Askarianzadeh, A., Imani, S., Shojaei, M., Larijani, K., and Abbasipour, H. (2017). "Identification of chemical compounds of the pheromone in different ages of female adults of the clearwing moth, Paranthrene diaphana Dalla Torre and Strand," Archives of Phytopathology and Plant Protection 50(19-20), 1019-1033. DOI: 10.1080/03235408.2017.1411174

Mohamed, H. A., Nasr, N. F., and Abdelkreem, K. I. (2015). "Management of tomato damping-off disease caused by Fusarium oxysporum and Rhizoctonia solani using chemical and biological degradable olive mill waste water," Egyptian Journal of Biological Pest Control 25(2), Article number 367-377.

Molinari, S. (2011). "Natural genetic and induced plant resistance, as a control strategy to plant-parasitic nematodes alternative to pesticides," Plant Cell Reports 30(3), 311323. DOI: $10.1007 / \mathrm{s} 00299-010-0972-\mathrm{z}$

Neves, O. S. C., Souza, A. S., Costa, M. A., Sousa, L. D. A., Viana, A. E. S., and Neves, V. B. F. (2014). "Persistência do cianeto e estabilização do pH em manipueira," Revista Brasileira de Tecnologia Agroindustrial 8(1), 1274-1284. DOI: 10.3895/S1981-36862014000100012 
Noushini, S., Perez, J., Park, S. J., Holgate, D., Jamie, I., Jamie, J., and Taylor, P. (2020). "Rectal gland chemistry, volatile emissions, and antennal responses of male and female banana fruit fly, Bactrocera musae," Insects 11(1), article no. 32. DOI: 10.3390/insects11010032

Ntalli, N., Adamski, Z., Doula, M., and Monokrousos, N. (2020). "Nematicidal amendments and soil remediation," Plants 9(4), 429. DOI: 10.3390/plants9040429

Núñez-Zofío, M., Larregla, S., Garbisu, C., Guerrero, M. M., Lacasa, C. M., and Lacasa, A. (2013). "Application of sugar beet vinasse followed by solarization reduces the incidence of Meloidogyne incognita in pepper crops while improving soil quality," Phytoparasitica 41(2), 181-191. DOI: 10.1007/s12600-012-0277-6

Ordaz-Diaz, L. A., Madrid-del Palacio, M., Rodriguez-Flores, F. J., and Bailón-Salas, A. M. (2019). "Aprovechamiento de los subproductos valiosos de la industria del mezcal en Durango [Taking advantage of the valuable by-products of the mezcal industry in Durango]," in: Colaboraciones de Cuerpos Académicos en Innovación Tecnológica [Collaborations of Academic Bodies in Technological Innovation], Ibero-American Network of Research Academies A.C., Veracruz, México, pp. 14-23.

Owuor, P. O. (2003). "TEA analysis and tasting," in: Encyclopedia of Food Sciences and Nutrition, B. Caballero (ed.), Academic Press, Cambridge, MA, USA, pp. 1-10.

Padmaja, G. (1995). "Cyanide detoxification in cassava for food and feed uses," Critical Reviews in Food Science and Nutrition 35(4), 299-339. DOI: 10.1080/10408399509527703

Papaianni, M., Paris, D., Woo, S. L., Fulgione, A., Rigano, M. M., Parrilli, E., Tutino, M. L., Marra, R., Manganiello, G., Casillo, A., et al. (2020). "Plant dynamic metabolic response to bacteriophage treatment after Xanthomonas campestris pv. campestris infection," Frontiers in Microbiology 11, Article Number 732. DOI: 10.3389/fmicb.2020.00732

Paslaru, A. I., Verhulst, N. O., Maurer, L. M., Brendle, A., Pauli, N., Vögtlin, A., Renzullo, S., Ruedin, Y., Hoffmann, B., Torgerson, P. R., et al. (2020). "Potential mechanical transmission of Lumpy skin disease virus (LSDV) by the stable fly (Stomoxys calcitrans) through regurgitation and defecation," Current Research in Insect Science 1, Article ID 100007. DOI: 10.1016/j.cris.2020.100007

Patzke, H., and Schieber, A. (2018). "Growth-inhibitory activity of phenolic compounds applied in an emulsifiable concentrate-ferulic acid as a natural pesticide against Botrytis cinerea," Food Research International 113, 18-23. DOI: 10.1016/j.foodres.2018.06.062

Paulitz, T. C., and Schroeder, K. L. (2005). "A new method for the quantification of Rhizoctonia solani and $R$. oryzae from soil," Plant Disease 89(7), 767-772. DOI: 10.1094/PD-89-0767

Peng, C., Zhang, G., Han, J., and Li, X. (2019). "Hydrothermal conversion of lignin and black liquor for phenolics with the aids of alkali and hydrogen donor," Carbon Resources Conversion 2(2), 141-150. DOI: 10.1016/j.crcon.2019.06.004

Pereira, C. S. M., Silva, V. M. T. M., and Rodrigues, A. E. (2011). "Ethyl lactate as a solvent: Properties, applications and production processes-A review," Green Chemistry 13(10), 2658-2671. DOI: 10.1039/c1gc15523g

Phanapavudhikul, S. (1999). "Direct use of spent distillery wash liquor on paddy fields in Thailand," Water and Environment Journal 13(6), 420-422. DOI: 10.1111/j.17476593.1999.tb01079.x 
Phillips, C. L., and Nickerson, N. (2015). "Soil respiration," in: Reference Module in Earth Systems and Environmental Sciences, S. Elias (ed.), Elsevier, Amsterdam, Netherlands, pp. 515-527. DOI: 10.1016/B978-0-12-409548-9.09442-2

Piłsyk, S., Natorff, R., Gawińska-Urbanowicz, H., and Kruszewska, J. S. (2015). "Fusarium sambucinum astA gene expressed during potato infection is a functional orthologue of Aspergillus nidulans astA," Fungal Biology 119(6), 509-517. DOI: 10.1016/j.funbio.2015.02.002

Pinto-Zevallos, D. M., Pereira-Querol, M., and Ambrogi, B. G. (2018). “Cassava wastewater as a natural pesticide: Current knowledge and challenges for broader utilization," Annals of Applied Biology 173(3), 191-201. DOI: 10.1111/aab.12464

Ponte, J. D., Franco, A., and Santos, J. H. R. D. (1988). “Teste preliminar sobre a utilização da manipuiera como inseticida [Preliminary test on the use of manipuiera as an insecticide]," Revista Brasileira de Mandioca 7, 89-90.

Ponte, J., and Franco, A. (1983). "Influencia da idade da manipueira na preservacao do potencial nematicida do composto (nota previa) [Influence of the age of the manipueira on the preservation of the nematicidal potential of the compound (previous note)]," Brazilian Society of Nematology 7, article ID 35215.

Puoci, F., Scoma, A., Cirillo, G., Bertin, L., Fava, F., and Picci, N. (2012). "Selective extraction and purification of gallic acid from actual site olive mill wastewaters by means of molecularly imprinted microparticles," Chemical Engineering Journal 198199, 529-535. DOI: 10.1016/j.cej.2012.05.095

Rashwan, R. S., and Hammad, D. M. (2020). "Toxic effect of Spirulina platensis and Sargassum vulgar as natural pesticides on survival and biological characteristics of cotton leaf worm Spodoptera littoralis," Scientific African 8, Article ID e00323. DOI: 10.1016/j.sciaf.2020.e00323

Ravindran, D. R., Bharathithasan, M., Ramaiah, P., Rasat, M. S. M., Rajendran, D., Srikumar, S., Ishak, I. H., Said, A. R., Ravi, R., and Amin, M. F. M. (2020). "Chemical composition and larvicidal activity against Aedes mosquitos of flower extracts from Clitoria ternatea," Journal of Chemistry 2020, 1-9. DOI: 10.1101/2020.03.31.018465

Rebollo-Romero, I., Fernández-Cruz, E., Carrasco-Galán, F., Valero, E., Cantos-Villar, E., Cerezo, A. B., Troncoso, A. M., and Garcia-Parrilla, M. C. (2020). "Factors influencing the production of the antioxidant hydroxytyrosol during alcoholic fermentation: Yeast strain, initial tyrosine concentration and initial must," LWT 130, Article ID 109631. DOI: 10.1016/j.lwt.2020.109631

Reddy, N., and Yang, Y. (2005). "Biofibers from agricultural byproducts for industrial applications," Trends in Biotechnology 23(1), 22-27. DOI:

10.1016/j.tibtech.2004.11.002

Regmi, H., and Desaeger, J. (2020). "Integrated management of root-knot nematode (Meloidogyne spp.) in Florida tomatoes combining host resistance and nematicides," Crop Protection 134, article ID 105170. DOI: 10.1016/j.cropro.2020.105170

Robles-González, V., Galíndez-Mayer, J., Rinderknecht-Seijas, N., and Poggi-Varaldo, H. M. (2012). "Treatment of mezcal vinasses: A review," Journal of Biotechnology 157(4), 524-546. DOI: 10.1016/j.jbiotec.2011.09.006

Rosazza, J. P. N., Huang, Z., Dostal, L., Volm, T., and Rousseau, B. (1995). "Review: Biocatalytic transformations of ferulic acid: An abundant aromatic natural product," Journal of Industrial Microbiology 15(6), 457-471. DOI: 10.1007/BF01570016 
Roy, R., Jadhav, B., Rahman, S., and Raynie, D. E. (2020). "Characterization of residue from catalytic hydrothermal depolymerization of lignin," Current Research in Green and Sustainable Chemistry 4, article ID 100052. DOI: 10.1016/j.crgsc.2020.100052

Rubin-Aguirre, A., Sáenz-Romero, C., Lindig-Cisneros, R., del-Rio-Mora, A. A., TenaMorelos, C. A., Campos-Bolaños, R., and del-Val, E. (2015). "Bark beetle pests in an altitudinal gradient of a Mexican managed forest," Forest Ecology and Management 343, 73-79. DOI: 10.1016/j.foreco.2015.01.028

Rubio-Senent, F., Fernández-Bolaños, J., García-Borrego, A., Lama-Muñoz, A., and Rodríguez-Gutiérrez, G. (2017). "Influence of $\mathrm{pH}$ on the antioxidant phenols solubilised from hydrothermally treated olive oil by-product (alperujo)," Food Chemistry 219, 339-345. DOI: 10.1016/j.foodchem.2016.09.141

Sadaria, A. M., Labban, C. W., Steele, J. C., Maurer, M. M., and Halden, R. U. (2019). "Retrospective nationwide occurrence of fipronil and its degradates in US wastewater and sewage sludge from 2001-2016," Water Research 155, 465-473. DOI: 10.1016/j.watres.2019.02.045

Saeed, Q., Ahmad, F., Iqbal, N., and Zaka, S. M. (2019). "Chemical control of polyphagous pests on their auxiliary hosts can minimize insecticide resistance: A case study of Spodoptera exigua Hübner (Lepidoptera: Noctuidae) in cotton agroecosystem," Ecotoxicology and Environmental Safety 171, 721-727. DOI: 10.1016/j.ecoenv.2019.01.038

Sanchez, S., Valadez-Rosales, M. F., Correa-Camacho, J. M., and Marino, E. (2019). "Recovery of phenolic compounds from Tequila vinasses using adsorption resins in two configurations (batch and continuous)," Journal of Chemical and Physical Energy 6(20), 1-6. DOI: 10.35429/JCPE.2019.20.6.1.6

Santos, A., and Ponte, J. D. (1993). Ação Fungicida da Manipueira No Controle de Oídio [Fungicidal Action of Manipueira in Powdery Mildew Control], Fitopatol, Lavras, Brazil, pp. 18, 302.

Santos, M., Diánez, F., De Cara, M., and Tello, J. C. (2008). "Possibilities of the use of vinasses in the control of fungi phytopathogens," Bioresource Technology 99(18), 9040-9043. DOI: 10.1016/j.biortech.2008.04.032

Sarip, H., Hossain, S., Azemi, M., and Allaf, K. (2016). "A review of the thermal pretreatment of lignocellulosic biomass towards glucose production: Autohydrolysis with DIC technology," BioResources 11(4), 10625-10653. DOI:

10.15376/biores.11.4.Sarip

Sassi, A. B., Boularbah, A., Jaouad, A., Walker, G., and Boussaid, A. (2006). “A comparison of olive oil mill wastewaters (OMW) from three different processes in Morocco," Process Biochemistry 41(1), 74-78. DOI: 10.1016/j.procbio.2005.03.074

Savary, S., Willocquet, L., Pethybridge, S. J., Esker, P., McRoberts, N., and Nelson, A. (2019). "The global burden of pathogens and pests on major food crops," Nature Ecology and Evolution 3, 430-439. DOI: 10.1038/s41559-018-0793-y

Saxena, S., and Strobel, G. A. (2020). "Marvellous Muscodor spp.: Update on their biology and applications,” Microbial Ecology 24, 1-16. DOI: 10.1007/s00248-02001644-0

Sedenho, G. C., Da Silva, J. L., Beluomini, M. A., De Sá, A. C., and Stradiotto, N. R. (2017). "Determination of electroactive organic acids in sugarcane vinasse by high performance anion-exchange chromatography with pulsed amperometric detection using a nickel nanoparticle modified boron-doped diamond," Energy \& Fuels 31(3), 2865-2870. DOI: 10.1021/acs.energyfuels.6b02783 
Shang, X., Dai, L., Yang, C., Guo, X., Liu, Y., Miao, X., and Zhang, J. (2020). “A valueadded application of eugenol as acaricidal agent: The mechanism of action and the safety evaluation," Journal of Advanced Research, In Press, Corrected proof available online. DOI: 10.1016/j.jare.2020.12.010

Sharma, A., Shukla, A., Attri, K., Kumar, M., Kumar, P., Suttee, A., Singh, G., PratapBarnwal, R. P., and Singla, N. (2020). "Global trends in pesticides: A looming threat and viable alternatives," Ecotoxicology and Environmental Safety 201, Article ID 110812. DOI: 10.1016/j.ecoenv.2020.110812

Simon-Delso, N., Amaral-Rogers, V., Belzunces, L. P., Bonmatin, J. M., Chagnon, M., Downs, C., Furlan, L., Gibbons, D. W., Giorio, C., Girolami, V., et al. (2014). "Systemic insecticides (neonicotinoids and fipronil): Trends, uses, mode of action and metabolites," Environmental Science and Pollution Research 22(1), 5-34. DOI: 10.1007/s11356-014-3470-y

Sleven, R., Lanckacker, E. A., Delputte, P. L., Maes, L., and Cos, P. (2016). "Evaluation of topical antifungal products in an in vitro onychomycosis model," Mycoses 59(5), 327-330. DOI: $10.1111 /$ myc. 12475

Soobadar, A., and Ng Kee Kwong, K. R. (2012). "Impact of high rates of vinasse on some pertinent soil characteristics and on sugarcane yield in Mauritius," Journal of Sustainable Agriculture 36(1), 36-53. DOI: 10.1080/10440046.2011.620226

Swett, C. L., Butler, B. B., Peres, N. A., Koivunen, E. E., Hellman, E. M., and Beaulieu, J. R. (2020). "Using model-based fungicide programing to effectively control Botrytis and Anthracnose fruit rots in Mid-Atlantic strawberry fields and co-manage strawberry sap beetle (Stelidota geminate).," Crop Protection 134, article no. 105175. DOI: $10.1016 /$ j.cropro.2020.105175

Tejada, M., García-Martínez, A. M., and Parrado, J. (2009). "Effects of a vermicompost composted with beet vinasse on soil properties, soil losses and soil restoration," CATENA 77(3), 238-247. DOI: 10.1016/j.catena.2009.01.004

Thakur, N., Kaur, S., Tomar, P., Thakur, S., and Yadav, A. N. (2020). "Microbial biopesticides: Current status and advancement for sustainable agriculture and environment," in: New and Future Developments in Microbial Biotechnology and Bioengineering, Elsevier, Amsterdam, Netherlands, pp. 243-282. DOI: 10.1016/B978-0-12-820526-6.00016-6

Tiwari, R. K., Kumar, R., Sharma, S., Sagar, V., Aggarwal, R., Naga, K. C., Lal, M. K., Chourasia, K. N., Kumar, D., and Kumar, M. (2020). "Potato dry rot disease: Current status, pathogenomics and management," 3 Biotech 10(11), Article Number 503. DOI: $10.1007 / \mathrm{s} 13205-020-02496-8$

Uğurlu, M., and Kula, I. (2007). "Decolourization and removal of some organic compounds from olive mill wastewater by advanced oxidation processes and lime treatment," Environmental Science and Pollution Research-International 14(5), 319325. DOI: $10.1065 /$ espr2006.06.315

Ullah, I., Khan, A. L., Ali, L., Khan, A. R., Waqas, M., Hussain, J., Lee, I., and Shin, J. H. (2015). "Benzaldehyde as an insecticidal, antimicrobial, and antioxidant compound produced by Photorhabdus temperata M1021," Journal of Microbiology 53(2), 127-133. DOI: 10.1007/s12275-015-4632-4

Varsha, K. K., Devendra, L., Shilpa, G., Priya, S., Pandey, A., and Nampoothiri, K. M. (2015). "2,4-Di-tert-butyl phenol as the antifungal, antioxidant bioactive purified from a newly isolated Lactococcus sp.," International Journal of Food Microbiology 211, 44-50. DOI: 10.1016/j.ijfoodmicro.2015.06.025 
Vigo, C., Norman, J. R., and Hooker, J. E. (2000). "Biocontrol of the pathogen Phytophthora parasitica by arbuscular mycorrhizal fungi is a consequence of effects on infection loci," Plant Pathology 49(4), 509-514. DOI: 10.1046/j.13653059.2000.00473.x

Villaverde, J. J., Sandín-España, P., Sevilla-Morán, B., López-Goti, C., and AlonsoPrados, J. L. (2016). "Biopesticides from natural products: Current development, legislative framework, and future trends," BioResources 11(2), 5618-5640. DOI: 10.15376/biores.11.2.Villaverde

Villegas, L. G. C., Mashhadi, N., Chen, M., Mukherjee, D., Taylor, K. E., and Biswas, N. (2016). "A short review of techniques for phenol removal from wastewater," Current Pollution Reports 2(3), 157-167. DOI: 10.1007/s40726-016-0035-3

Wang, F. (2020). "Determination of lignin concentration in bleaching effluent via Coomassie brilliant blue G-250 method," BioResources 15(1), 228-239. DOI: 10.15376/biores.15.1.228-239

Wang, Y., Liu, H., Zhang, D., Liu, J., Wang, J., Wang, S., and Sun, B. (2019). "Baijiu vinasse extract scavenges glyoxal and inhibits the formation of $\mathrm{N} \varepsilon$-carboxymethyllysine in dairy food," Molecules 24(8), Article ID 1526. DOI: 10.3390/molecules24081526

Watthier, E., Andreani, C. L., Torres, D. G. B., Kuczman, O., Tavares, M. H. F., Lopes, D. D., and Gomes, S. D. (2019). "Cassava wastewater treatment in fixed-bed reactors: Organic matter removal and biogas production," Frontiers in Sustainable Food Systems 3, Article number 6. DOI: 10.3389/fsufs.2019.00006

Wedge, R. M., Abt, E. N., and Hobbs, C. H. (2001). "Methyl bromide risk characterization in California," Journal of Toxicology and Environmental Health Part B: Critical Reviews 4(3), 333-339. DOI: 10.1080/10937400119036

Wingfield, M. J., Brockerhoff, E. G., Wingfield, B. D., and Slippers, B. (2015). "Planted forest health: The need for a global strategy," Science 349(6250), 832-836. DOI: 10.1126/science.aac6674

Xin, X., Kvitko, B., and He, S. Y. (2018). "Pseudomonas syringae: What it takes to be a pathogen," Nature Reviews Microbiology 16(5), 316-328. DOI: 10.1038/nrmicro.2018.17

Yang, Z., Yu, Z., Lei, L., Xia, Z., Shao, L., Zhang, K., and Li, G. (2012). "Nematicidal effect of volatiles produced by Trichoderma sp.," Journal of Asia-Pacific Entomology 15(4), 647-650. DOI: 10.1016/j.aspen.2012.08.002

Yangui, T., Dhouib, A., Rhouma, A., and Sayadi, S. (2009). "Potential of hydroxytyrosol-rich composition from olive mill wastewater as a natural disinfectant and its effect on seeds vigour response," Food Chemistry 117(1), 1-8. DOI: 10.1016/j.foodchem.2009.03.069

Yangui, T., Sayadi, S., Rhouma, A., and Dhouib, A. (2010). "Potential use of hydroxytyrosol-rich extract from olive mill wastewater as a biological fungicide against Botrytis cinerea in tomato," Journal of Pest Science 83(4), 437-445. DOI: 10.1007/s10340-010-0314-5

Zema, D. A., Lucas-Borja, M. E., Andiloro, S., Tamburino, V., and Zimbone, S. M. (2019). "Short-term effects of olive mill wastewater application on the hydrological and physico-chemical properties of a loamy soil," Agricultural Water Management 221, 312-321. DOI: 10.1016/j.agwat.2019.04.011 
Zhang, M., Wang, Z., Li, P., Zhang, H., and Xie, L. (2017). "Bio-refractory dissolved organic matter and colorants in cassava distillery wastewater: Characterization, coagulation treatment and mechanisms," Chemosphere 178, 259-267. DOI:

10.1016/j.chemosphere.2017.03.065

Article submitted: January 24, 2021; Peer review completed: May 8, 2021; Revisions accepted: May 12, 2021; Published: May 14, 2021.

DOI: 10.15376/biores.16.3.Bailon-Salas 